\title{
Dental Enamel Around Fixed Orthodontic Appliances after Fluoride Varnish Application
}

\author{
Leonardo GONTIJO ${ }^{1}$ \\ Roberval de Almeida CRUZ ${ }^{1}$ \\ Paulo Roberto Gomes BRANDÃO² \\ ${ }^{1}$ School of Dentistry, Pontifical Catholic University of Minas Gerais, Belo Horizonte, MG, Brazil \\ ${ }^{2}$ School of Engineering, Federal University of Minas Gerais, Belo Horizonte, MG, Brazil
}

\begin{abstract}
Poor oral hygiene has been considered one of the main problems routinely faced in the orthodontic treatment. Orthodontic appliance creates an environment that provides mineral loss from the dental enamel. Such condition is clinically seen as white spot lesions and cavitations in the most severe cases. The aim of this study was to evaluate the effects of a fluoride varnish application as a caries prevention method for clinical orthodontics. The experiment analyzed dental enamel adjacent to orthodontics accessories after treatment. In addition, it was observed the calcium, phosphorus and fluoride contents on enamel treated with a fluoride varnish. The results showed that fluoride varnish application is a simple and fast technique that could be useful in preventing enamel demineralization associated to orthodontic treatment. Scanning electron microscopy revealed significant amount of calcium fluoride-like material deposited on enamel and energy dispersive x-ray analysis demonstrated a large incorporation of calcium and fluoride to the enamel of the treated specimens. It was concluded that fluoride varnish could indeed be considered an efficient preventive method to enhance enamel resistance against the cariogenic challenges during orthodontic therapy.
\end{abstract}

Key Words: orthodontics appliances, fluoride varnish, demineralization.

\section{INTRODUCTION}

Orthodontics has faced a number of important technological advances during the last decades. A wide variety of new materials, different treatment modalities, and new diagnostic aids have been incorporated to the orthodontic practice, resulting in a remarkable improvement of the service quality provided to the patients. However, orthodontists are still challenged by an "old problem" in their clinics: enamel demineralization around orthodontic appliances.

Patients undergoing orthodontic therapy are exposed to a higher risk of enamel demineralization. Appliances are directly attached to tooth surface increasing the difficulty of achieving adequate oral hygiene. Some of commonly used accessories, such as hooks, posts, elastic chains and springs, can also undermine dental biofilm removal. Thus, the incidence of white spot lesions can be significantly higher among orthodontic patients with poor oral hygiene (1).
The lack of patient's cooperation and consequent poor oral hygiene is one of the main challenges in orthodontic practice (2). Sometimes, treatment withdrawal is required to reach an adequate oral health status. Thus, preventive and therapeutic measurements before orthodontic treatment start may be required to minimize the risk of developing caries lesions and to ensure that the patient will have sound enamel structure in all teeth after completion of the orthodontic treatment.

It has been demonstrated that topical fluoride application induces deposition of calcium fluoride-like material $\left(\mathrm{CaF}_{2}\right)$ on enamel surface. $\mathrm{CaF}_{2}$ remains available on enamel and in the dental biofilm during weeks after the orthodontic treatment starts $(3,4)$. Therefore, fluoride varnish may represent an alternative material to prevent caries onset in orthodontic patients. Available in the market for more than 30 years and thoroughly studied and used in Europe, fluoride varnish presents high fluoride concentrations. Its application technique is simple and fast. The varnish is not affected by humidity, 
remains adhered to enamel during a significant period of time and its use does not require patient cooperation $(5,6)$. In addition, for patients treated with fixed appliances, fluoride varnishes can be applied only in areas that present higher risk of demineralization. All these characteristics indicate that varnish application may be easily incorporated to the daily clinic routine (7).

This study evaluated, in vitro, the effect of topical fluoride varnish application on enamel around orthodontic brackets bonded with a composite resin.

\section{MATERIAL AND METHODS}

The sample consisted of 16 human premolars scheduled for extraction due to orthodontic reasons from patients of the School of Dentistry of the Pontifical Catholic University of Minas Gerais. Inclusion criteria were absence of any clinical evidence of demineralization lesions, lack of visible structural defects on enamel and no restorations on surface. Patients were from both sexes, ranged in age from 13 to 23 years and lived in the city of Belo Horizonte (Brazil), where the supplying water contains approximately $0.7 \mathrm{ppm}$ of fluoride. The patients were evaluated during a 28-day period and did not use any kind of fluoride supplement during the experimental period, except fluoridated toothpastes (approximately $1500 \mathrm{ppm} \mathrm{F}^{-}$). The patients were duly informed about the study and signed informed consent forms. The research protocol was reviewed by the Ethics in Research Committee of the Pontifical Catholic University of Minas Gerais and the study design was approved.

Before bracket bonding, buccal surfaces of the premolars were polished with a rubber cup and fluoridefree prophylactic paste, rinsed with a three-way air/ water syringe and carefully dried. A 37\% phosphoric acid gel was applied to the enamel surface area corresponding to the bracket base for $15 \mathrm{~s}$ (8). The acid gel was removed with water, tooth surface was dried and the bracket was bonded to the center of the crown with a fluoride-free self-curing composite (Rely A Bond ${ }^{\circledR}$; Reliance Orthodontic Products, Itasca, Il, USA). After bracket bonding, the right premolars (test side) were kept dried by careful tooth isolation and the enamel received a single topical application of a fluoride varnish (Duraphat ${ }^{\circledR}$; Woelm and Pharma Co., Eschwege, Germany) with the aid of a brush applicator. Three minutes later, isolation was removed and the teeth were wet with mild air/water spray. The left premolars were used as controls (i.e., did not receive any varnish application) and brackets were fixed using identical procedures. Patients were advised to avoid eating for the following hour and only brush their teeth $12 \mathrm{~h}$ after bonding. After 28 days, teeth were extracted carefully to avoid accidental bracket removal and enamel damage. The extracted premolars were individually stored in closed dried plastic containers and maintained at $4^{\circ} \mathrm{C}$. Before laboratorial analysis, teeth were rinsed with ethanol for $60 \mathrm{~s}$ to remove organic substances and debris from enamel without fluoride dissolution(3). Finally, premolars were dried, mounted on metal stubs and sputter-coated with carbon (Denton Vacuum, Moorestown, NJ, USA), as recommended by Massara et al. (9).

The samples were analyzed with a scanning electron microscope (JEOL JSM 5410, Tokyo, Japan), which was connected to an energy-dispersive x-ray spectrometer (EDS) (Noram Instruments, Middleton, WI, USA) with a standardized integrated reading time of $100 \mathrm{~s}$ per surface area of $1 \mu^{2}$, following the manufacturer's specifications. Eight analyses for each tooth, two above, two below, two on the right and two on the left surface of the bracket were performed. A total of 64 analyses were done in each group (experimental and control). The areas were chosen at random and the readings were done as close as possible to the bracket base. Thus, elementary chemical analyses for calcium, phosphorus and fluoride were obtained.

Data were analyzed using descriptive measures by Wilcoxon non-parametric test was performed. Significance level was set at $5 \%$.

\section{RESULTS}

Examination of enamel surfaces adjacent to orthodontic brackets revealed significant calcium fluoride-like material $\left(\mathrm{CaF}_{2}\right)$ deposition as a reaction product of varnish topical application (Fig. 1). An adhered thin layer of varnish was also seen in some teeth of the test group, which was in close contact with the enamel around the orthodontic brackets (Fig. 2).

EDS results showed that the experimental group differed significantly from the control group $(\mathrm{p}<0.05)$ regarding all mineral components (calcium, phosphorus and fluoride). The test group showed higher calcium and fluoride contents. However, higher phosphorus content was observed in the control group (Table 1). 

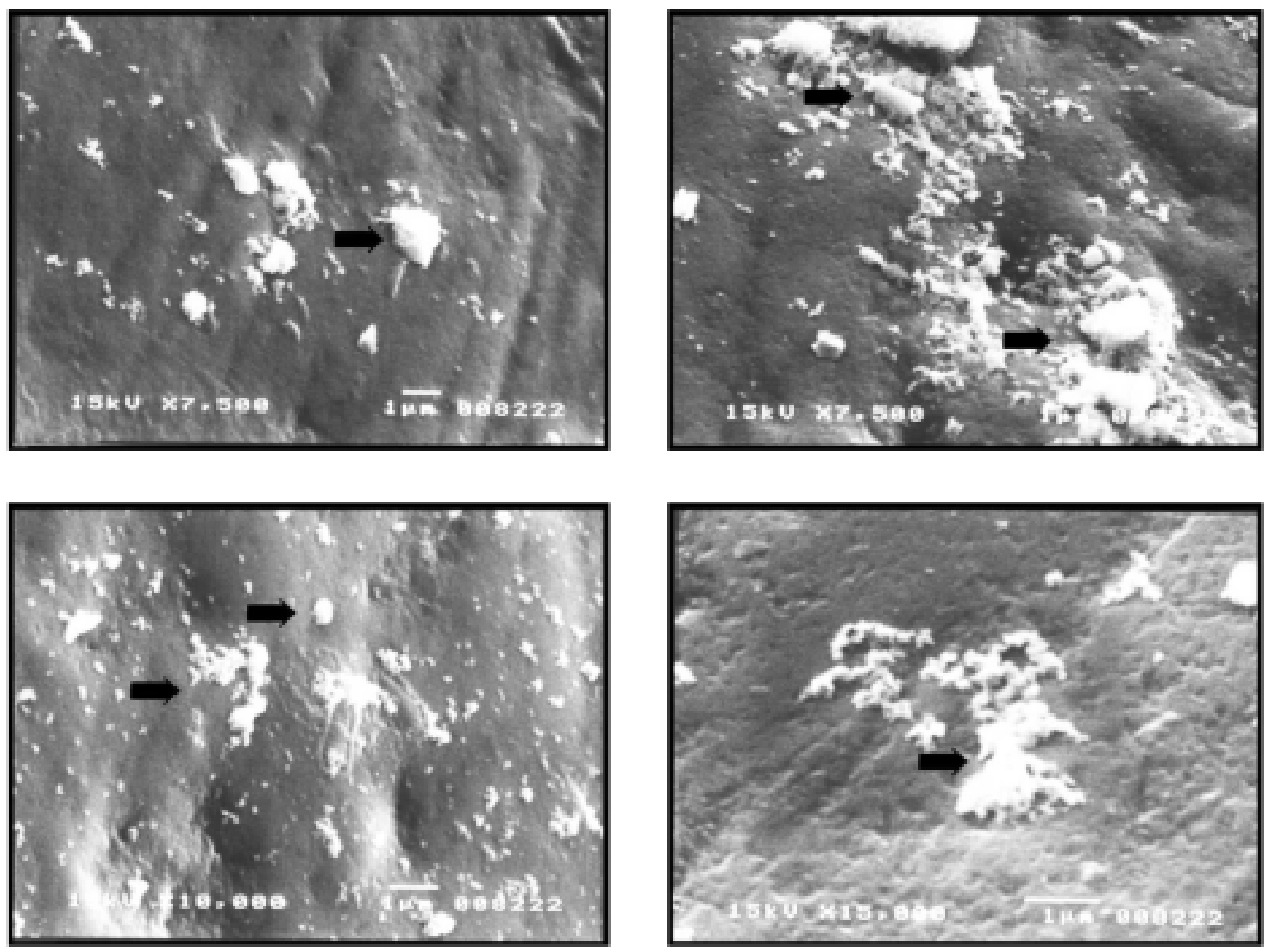

Figure 1. Calcium fluoride-like material on enamel adjacent to orthodontic brackets. Note the globular aspect (arrows). Original magnification: 7500X, 10000X and 15000X.

Table 1. Comparison among the groups regarding fluoride, phosphorus and calcium contents.

\begin{tabular}{lccccc}
\hline Minerals & \multicolumn{5}{c}{ Descriptive measures } \\
\cline { 2 - 6 } & $\begin{array}{l}\text { Min. } \\
\text { value }\end{array}$ & $\begin{array}{c}\text { Max. } \\
\text { value }\end{array}$ & & $\begin{array}{c}\text { Means } \\
( \pm \mathrm{SD})\end{array}$ & $\begin{array}{c}p \\
\text { value }\end{array}$ \\
\hline Fluoride & & & & & \\
Test & 0.05 & 8.93 & 0.54 & $1.70 \pm 3.00$ & 0.014 \\
Control & 0.00 & 0.00 & 0.00 & $0.00 \pm 0.00$ & $\mathrm{G}_{\mathrm{T}}>\mathrm{G}_{\mathrm{C}}$ \\
& & & & & \\
$\begin{array}{l}\text { Phosphorus } \\
\text { Test }\end{array}$ & 18.94 & 30.03 & 28.85 & $27.44 \pm 3.69$ & 0.021 \\
Control & 8.80 & 31.45 & 30.04 & $30.18 \pm 0.95$ & $\mathrm{G}_{\mathrm{T}}<\mathrm{G}_{\mathrm{C}}$ \\
& & & & & \\
Calcium & & & & & \\
$\begin{array}{l}\text { Test } \\
\text { Control }\end{array}$ & 69.92 & 72.62 & 70.49 & $70.86 \pm 1.02$ & 0.030 \\
& 68.55 & 71.21 & 69.96 & $69.82 \pm 0.95$ & $\mathrm{G}_{\mathrm{T}}>\mathrm{G}_{\mathrm{C}}$
\end{tabular}

The probability significance relates to Wilcoxon test. $\mathrm{G}_{\mathrm{T}}=$ test group; $\mathrm{G}_{\mathrm{C}}=$ control group.

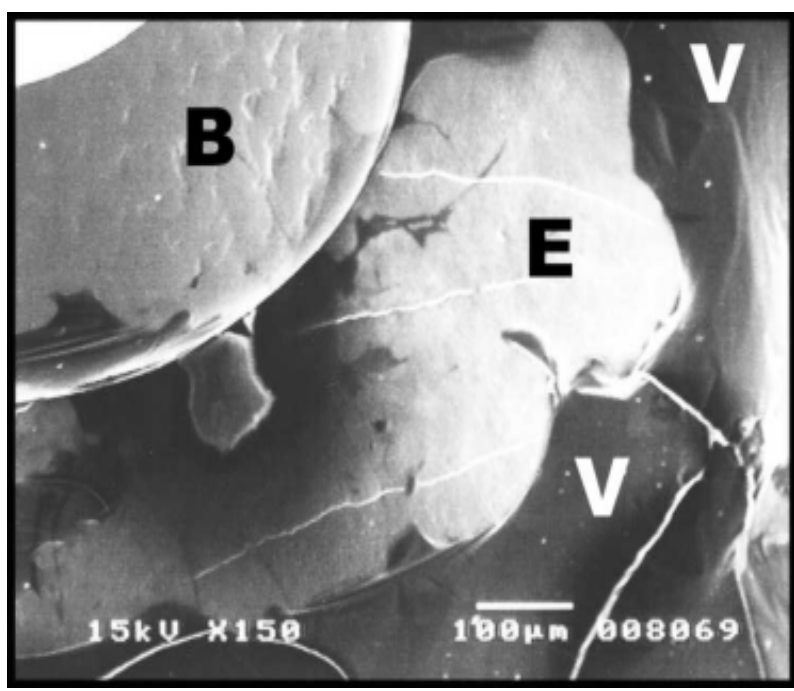

Figure 2. SEM micrograph showing a layer of Duraphat ${ }^{\circledR}$ fluoride varnish (V) adhered to the enamel surface (E) around the attached orthodontic bracket (B). Original magnification: $150 X$. 


\section{DISCUSSION}

This study investigated whether fluoride varnish application could improve the local condition of dental enamel areas with high risk of demineralization.

In this study, it was demonstrated by SEM that fluoride varnish reacts with dental enamel around orthodontic brackets and the reaction product deposited seems to be calcium fluoride. According to Ögaard (4), calcium fluoride is the largest and the most important reaction product formed on enamel after topical application of any fluoride-containing material. Calcium fluoride has also been considered a fluoride ions reservoir, which can be used for enamel protection during higher cariogenic challenges in the oral cavity (10).

SEM also showed, in some teeth, an adhered layer of varnish close to the bracket. Such observations are similar to those reported by Stookey (11) and Petersson (12). This lacquer may protect the deposited calcium fluoride against dissolution, which means to extend the benefits of this reaction on enamel (3). On the other hand, EDS is defined as a quantitative, semi quantitative or qualitative method for identification of chemical elements in a wide variety of samples. The technique sensitivity of this method depends on the atomic number of the element to be identified, the atomic number of all elements present in the sample and the technique used during sample preparation for microanalysis (13). The present study analyzed only calcium, phosphorus and fluoride, whose atomic numbers are 20,15, and 9, respectively. EDS can quantitatively analyze calcium and phosphorus, which have higher atomic numbers. However, this method of chemical element identification can evaluate the presence of fluoride only qualitatively.

As it was described, during preparation, the specimens were sputter-coated with carbon, instead of gold, for SEM and EDS examinations. Although gold provides better SEM images, it has been suggested that gold coating might interfere negatively with phosphorus identification by the microanalyzer (9).

The results of this experiment showed a significant difference in calcium, phosphorus and fluoride contents in the test group compared to the control group. Statistical analysis showed higher levels of calcium and fluoride in the experimental group of teeth. Based on this observation, one could assume that there was indeed a larger calcium fluoride deposition on the teeth treated with topical fluoride varnish application.

EDS analysis revealed higher phosphorus content in the control group, which could be explained by the greater presence of calcium and fluoride in the test group. In other words, an increment in calcium and fluoride content is dependent on a decrease in phosphorus content. These findings are directly correlated to the method of analysis used in this experiment. In each studied area, only three chemical elements of interest were evaluated. Therefore, the sum of the amount of these elements was always $100 \%$. As a result, in the teeth with higher percentages of fluoride and calcium, phosphorus content decreased. These findings corroborate those of Skartveit et al. (14) that applied the same method of fluoride determination on primary enamel treated with fluoridated filling materials.

Thus, topical application of fluoride varnish on enamel adjacent to orthodontic accessories, incorporated as a routine clinical preventive procedure, represents a simple measure of great significance (15). It is strongly recommended for decreasing the risk of enamel demineralization during orthodontic treatment.

\section{RESUMO}

Um dos maiores problemas enfrentados na clínica ortodôntica é a dificuldade de higienização em função da presença do aparelho fixo e seus componentes. Associado muitas vezes à pouca colaboração do paciente, o tratamento ortodôntico pode criar condições para a perda de estrutura mineral do esmalte, refletida por manchas brancas e até cavitações nos casos mais severos. Este trabalho teve como objetivo verificar a aplicabilidade do verniz fluoretado como método preventivo na clínica ortodôntica. Assim, procurou-se investigar o aspecto do esmalte dental adjacente aos acessórios ortodônticos, bem como determinar o conteúdo dos elementos cálcio, fósforo e flúor nas superfícies tratadas com o verniz em comparação com um controle. Os resultados mostraram, por meio de microscopia eletrônica de varredura, o produto reacional (semelhante ao fluoreto de cálcio) decorrente da aplicação local. A espectrometria de raios X por dispersão de energia mostrou ainda ter havido maior teor de cálcio e flúor no esmalte tratado. Conclui-se que o verniz fluoretado pode efetivamente conferir proteção ao esmalte dental, durante os desafios cariogênicos, tendo indicação para o emprego nos pacientes em tratamento ortodôntico.

\section{REFERENCES}

1. Burkland G. Hygiene and the orthodontic patient. J Clin Orthod 1999;33:443-446.

2. White LW. Oral hygiene for orthodontic patients. J Clin Orthod 1996;30:340-341.

3. Cruz RA, Ögaard B, Rölla G. Uptake of KOH-soluble and 
$\mathrm{KOH}$-insoluble fluoride in sound human enamel after topical application of fluoride varnish (Duraphat ${ }^{\circledR}$ ) or a neutral 2\% NaF solution in vitro. Scand J Dent Res 1992;100:154-158.

4. Ögaard B. $\mathrm{CaF}_{2}$ formation: cariostatic properties and factors of enhancing the effect. Caries Res 2001;35:40-44.

5. Petersson LG. Fluoride mouth rinses and fluoride varnishes. Caries Res 1993;27:35-42.

6. Sëppa L, Pöllanen L, Hausen H. Caries-preventive effect of fluoride varnish with different concentrations. Caries Res 1994;28:64-67.

7. Todd MA, Staley RN, Kanellis MJ, Donly KJ, Wefel JS. Effect of a fluoride varnish on demineralization adjacent to orthodontic brackets. Am J Orthod Dentofacial Orthop 1999;116:159-167.

8. O’Reilly MM, Featherstone JDB. Demineralization and remineralization around orthodontic appliances: an in vivo study. Am J Orthod Dentofacial Orthop 1987;92:33-40.

9. Massara MLA, Alves JB, Brandao PR. Atraumatic restorative treatment: clinical, ultrastructural and chemical analysis. Car- ies Res 2002;36:430-436.

10. Rölla G. On the role of calcium fluoride in the cariostatic mechanism of fluoride. Acta Odont Scand 1988;28:341-345.

11. Stookey GK. Critical evaluation of composition and use of topical fluorides. J Dent Res 1990;69:805-812.

12. Petersson LG. Fluoride mouth rinses and fluoride varnishes. Caries Res 1993;27:35-42.

13. Jenkins R. X ray Fluorescence spectrometry. New York: John Wiley; 1988.

14. Skartveit L, Tveit AB, Tötdal B, Ovrebo R, Raadal M. In vivo fluoride uptake in enamel and dentin from fluoride-containing materials. ASDC J Dent Child 1990;57:97-100.

15. Schmit JL, Staley RN, Wefel J, Kanellis M, Jakobsen JR, Keenan PJ. Effect of fluoride varnish on demineralization adjacent to brackets bonded with RMGI cement. Am J Orthod Dentofacial Orthop 2002;122:125-134.

Accepted July 9, 2004 